\title{
ZWIERZĘ JAKO PODMIOT. O METASTRATEGIACH KOLONIZOWANIA PRZYRODY
}

\author{
HANNA MAMZER ${ }^{1}$ \\ (Uniwersytet im. Adama Mickiewicza w Poznaniu)
}

Słowa klucze: kolonizowanie przyrody, strategie kolonizowania, upodmiotowienie przyrody, zwierzę

Keywords: colonization, empowering nature, ecology, animal

\begin{abstract}
Abstrakt: Hanna Mamzer, ZWIERZE, JAKO PODMIOT. O METASTRATEGIACH KOLONIZOWANIA PRZYRODY. „PORÓWNANIA”, 15, 2014, T. XV, s. 75-90. ISSN 1733-165X. Społeczeństwa postindustrialne realizują formy kolonizacji, które sięgają społeczności tradycyjnych. Rewolucja przemysłowa wyposażyła cywilizację Zachodu w narzędzia, pozwalające kolonizować w wymiarze kulturowym, i wymiarze podporządkowywania przyrody. Proceder ten jest dzisiaj mocno zaawansowany - na szczęście jednak budzić zaczyna opór, ze strony aktywistów pro-ekologicznych, których działania zmierzają do uznania zwierzęcia jako pełnoprawnego podmiotu. Strategie oporu wobec kolonizowania przyrody są realizowane w postaci różnego rodzaju ruchów. Wszystkie one zmierzają do uprawomocnienia postrzegania przyrody, w tym zwierząt jako pełnoprawnych podmiotów korzystających z zasobów Ziemi, co do których człowiek uzurpuje sobie prawo nieograniczonej eksploatacji. Czy można mówić o meta-strategiach, które były i są wykorzystywane do kolonizowania?
\end{abstract}

\begin{abstract}
Hanna Mamzer, ANIMAL AS A SUBJECT. ON META-STRATEGIES OF COLONIZING THE NATURE. "PORÓWNANIA", 15, 2014, Vol. XV, p. 75-90. ISSN 1733-165X. Postindustrial societies undertake forms of colonization, which derive from specificity of agriculturally-based societies. Industrial revolution had equipped human kind in tools that are being applied in order to conquest the natural world. In contemporary humanistic discourse one can observe stronger and stronger stream of discussing issues related to human domination and exploitation of the nature. All of protets against those procedures aim at empowering natural surroundings of human kind in order to limit colonization process. While looking at colonization in socio-cultural aspects and environmental aspects, one may notice many similarities. Is it possible to name meta-strategies used in colonization processes?
\end{abstract}

\footnotetext{
${ }^{1}$ Correspondence Address: mamzer@amu.edu.pl
} 
Joanna Bednarek, rekonstruując definicję podmiotu proponowaną przez Rosi Braidotti, pisze tak we wstępie do jej pracy zatytułowanej Po człowieku:

Braidotti, proponuje wizję świata, w którym komunikacja tego, co wzajemnie nieredukowalne, jest normą, a podmiot definiowany już nie przez wąsko rozumianą samoświadomość, refleksyjność czy rozumność, ale przez zdolność tworzenia powiązań wspólną ludziom i zwierzętom - przestaje być kategorią antropocentryczną².

Ta definicja podmiotu jest mi bliska - tym bardziej, jeśli wsparta dodatkowo na rozważaniach Paula Ricoeura ${ }^{3}$, podkreślających rolę rozpoznania w interlokutorze podmiotu, poprzez uznanie go za równorzędnego, godnego partnera interakcji. Przyjęcie założeń tego rodzaju sankcjonuje uznanie zwierzęcia za podmiot. Dziać się to może jednak jedynie $w$ kontekście szerszych zmian społecznych zmierzających do ograniczania dominacji człowieka nad otaczającą go przyrodą, które można rozważać w kategoriach procesów post-kolonizacyjnych, ujawniających się jako protest wobec kolonizowania świata - świata przyrody. W tym sensie prowadzenie rozważań o zwierzęciu-podmiocie stanowi pewnego rodzaju uszczegółowienie szerszego dyskursu na temat kondycji ludzkiej i jej odniesienia do kondycji nieludzkiej.

Trafnie ujął to zagadnienie Charles Taylor w Etyce autentyczności, pisząc:

Kiedy społeczeństwo traci uświęconą strukturę, kiedy instytucje społeczne i sposoby postępowania przestają być zakorzenione $\mathrm{w}$ porządku rzeczy albo $\mathrm{w}$ woli Bożej, w pewnym sensie stają się niczyje. Można je przemodelować mając na względzie ich konsekwencje dla szczęścia i dobrobytu jednostek. Od tej chwili naszym probierzem stają się kryteria rozumu instrumentalnego. Analogicznie, gdy towarzyszące nam stworzenia utracą znaczenie, przysługujące im $\mathrm{w}$ ramach łańcucha bytu, nic nie stoi na przeszkodzie, by traktować je jako surowce albo narzędzia służące naszym celom4.

Rysowana przez Taylora perspektywa jest groźna, bowiem jeśli uzasadniać działania jedynie ich instrumentalnością (przydatnością do osiągnięcia jakiegoś celu), to można spodziewać się wszystkiego. Jeśli można tak traktować zwierzęta, to dlaczego nie ludzi? Albo nie niepełnosprawne dzieci - retorycznie zapytuje Peter Singer ${ }^{5}$, niejako kontynuując rozważania Taylora.

Chociaż dyskurs związany z pojęciem kolonizacji, a w szczególności postkolonializmu, w dzisiejszej humanistyce jest zdecydowanie ukierunkowany na analizę zagadnień związanych z dominacją kulturową, dostrzec można już pewien intere-

${ }^{2}$ J. Bednarek, Nowa kartografka wspótczesności. Przeł. J. Bednarek, A. Kowalczyk. W: Po człowieku. R. Braidotti. Warszawa 2014, s. 29.

3 P. Ricoeur, Drogi rozpoznania. Przeł. J. Margański. Kraków 2004.

${ }^{4}$ Ch. Taylor, Etyka autentyczności. Przeł. A. Pawelec. Kraków 1996, s. 12.

${ }^{5}$ W obronie zwierząt. Red. P. Singer. Przeł. M. Betley. Warszawa 2011. 
sujący rys, adaptujący aparat teoretyczny już wypracowany w ramach tych analiz, na nowy-stary obszar: kolonizowania przyrody. Klasyczne prace Edwarda Saida6 i Franza Fanona7, już kanoniczne dla dyskursu postkolonialnego - zmierzającego do destabilizacji tych teorii, które stanowią wsparcie intelektualne dla zachodniokulturowo zakorzenionych sposobów myślenia o reszcie świata - znajdują nowe zastosowanie, są „przekładane” na poziom dyskusji dotyczący kolonizowania przyrody. Teorie postkolonialne próbują uporać się z sytuacją dominacji jednego typu dyskursu, tego właśnie, który jest narzucany całemu światu ludzkiemu, w zasadzie $\mathrm{z}$ perspektywy europocentrycznej. W tym sensie postkolonializm, stanowiący opozycję wobec europocentrycznego, dominującego punktu widzenia, tworzy przestrzeń budowania równowagi pomiędzy tym, co europejskie, a tym, co poza Europą.

Jak trafnie wskazują przywołani wyżej klasycy, znaczna część dominacji europejskiego punktu widzenia, kulturowego kolonizowania obszarów pozaeuropejskich, jest realizowana dzięki strategiom językowym i narracyjnym, uprzedmiotawiającym Innego. Zajmowałam się tymi zagadnieniami w innych miejscach ${ }^{8}$, analizując zjawisko nie tyle z lingwistycznego punktu widzenia, ile traktując je jako wyraz wytwarzanych kulturowo tekstów, rozumianych szeroko - w duchu przełomu tekstualnego. Każdy kulturowy wytwór, a więc każdy "tekst”, stanowi tam reprezentację pewnego oglądu rzeczywistości, który za pośrednictwem tegoż właśnie "tekstu”, jest komunikowany na zewnątrz. W tym sensie interesowało mnie bardziej, jak język tekstu kulturowego odzwierciedla stosunek do Innego, definiowanego w kategoriach proponowanych przez Emmanuela Lévinasa ${ }^{9}, 10$.

W omawianym tekście starałam się zidentyfikować strategie stosowane wobec kulturowego (etnicznego) Innego, które sprowadzają go do pozycji przedmiotu. Strategiami tymi są: odebranie imienia, przedstawianie osoby nie jako indywidualnego podmiotu, ale przedstawiciela grupy, wykorzystywanie grupy ludzi jako tła dla jednej, wybijającej się jednostki; pozostawienie osób w nieświadomości co do tego, co się z nimi dzieje (np. fotografowanie ich i potem wykorzystywanie bez

6 E. Said, Orientalizm. Przeł. M. Wyrwas-Wiśniewska. Poznań 2005.

${ }^{7}$ F. Fanon, Wyklęty lud ziemi. Przeł. H. Tygielska. Warszawa 1985.

${ }^{8} \mathrm{H}$. Mamzer, Inny uprzedmiotowiony? Jak mówić o wielokulturowości. W: Czy kres wielokulturowości? Red. H. Mamzer. Poznań 2008, s. 61-79.

${ }^{9} \mathrm{~W}$ tekście tym prezentowałam wizualne cytaty - fotografie mody, która była prezentowana przez białe modelki w etnicznie innych kontekstach kulturowych - w Indiach lub krajach afrykańskich, gdzie ludność autochtoniczna traktowana była jako tło dla białej modelki, a w zasadzie prezentowanych przez nią ubrań znanych projektantów mody. Tego rodzaju praktyki skłoniły mnie do podjęcia krytycznej refleksji nad tym, jak w zasadzie należy mówić o inności kulturowej, by jednocześnie nie zatracać centralnej perspektywy podmiotowego traktowania przedstawicieli grup etnicznych.

${ }^{10}$ E. Lévinas, Istniejący i istnienie. Przeł. J. Margański. Kraków 2006. 
ich zgody tych zdjęć), itd. Strategii tych można wymienić więcej, jednak wszystkie one zmierzają do depersonalizacji i deprecjacji. Obniżenie wartości drugiego człowieka, a także odebranie mu indywidualności, to podstawa do realizowania praktyk behawioralnych, zmierzających do wykorzystania, a więc kolonizowania.

Co więcej, w ramach wszelkiego rodzaju kolonizacji, aby mogła ona być realizowana zarówno poprzez strategie językowe, kognitywne czy te jak najbardziej dosłownie - praktyczne, niezbędne jest tworzenie binarnych opozycji opartych na hierarchizowaniu, co pozwala zdefiniować, kto/co jest kolonizatorem, a kto/co - kolonizowanym. Zbudowanie tej opozycji jest warunkiem sine qua non dla skutecznego działania kolonizującego. Te strategie tak samo buduje się wobec odmienności kulturowych, jak wobec każdego „innego świata, który chce się kolonizować". W dalszej części tekstu będę chciała wskazać na znaczenie nabierającego na sile nurtu adaptowania wypracowanego $\mathrm{w}$ ramach postkolonializmu aparatu pojęciowego w kierunku omawiania zagadnień związanych z kwestiami bliskimi dziedzinom podejmującym problematykę gender, płci kulturowej. Gdyby tradycyjnie pojmowane role społeczne chcieć widzieć jako powiązane z biologicznymi różnicami wynikającymi z płci człowieka, w tym rodzaju odłamu dyskusji można dostrzec ukłon w stronę elementów biologicznych. Piszę o tym dlatego, że warto pamiętać, że kolonizacja jako proces zdobywania i zajmowania obszarów poza granicami własnego kraju, państwa czy nawet szerzej - terytorium (także w sensie merytorycznym), rozpoczęła się od dążeń mocarstwowych, podyktowanych chęcią zdominowania i eksploatacji przyrody, rozumianej szeroko - przede wszystkim jako zasoby naturalne.

W tym kontekście bardzo chciałabym widzieć pewien rodzaj zwrotu, który można by analizować linearnie: analiza procesów kolonizacji w kontekście przejmowania władzy nad przyrodą, następnie analiza kolonizacji rozumianej jako dominacja kulturowa, aż do analizy kolonizacji ujmowanej w kategoriach „post”a więc postkolonializmu. Ten chciałabym rozumieć szeroko - jako protest wobec kolonizowania, rozumianego jako zdobywanie dominacji czy uzurpowanie jej sobie nad kulturą, społecznościami czy kategoriami społecznymi (czy wieloma innymi wymiarami, by wspomnieć choćby postkolonizację języka), ale również nad przyrodą. $W$ tym sensie, moim zdaniem, proces postkolonizacji zyskuje wieloaspektowość w zakresie analizowanego „przedmiotu kolonizacji”.

Myślę, że mamy dziś do czynienia z pojawianiem się w analizach kolonializmu i postkolonializmu trendu narzucającego w pewnym sensie ujęcie holistyczne (czy może uniwersalistyczne), mówiące o człowieku jako takim. Poza różnorodnymi dominacjami jednych grup na drugimi czy danych grup nad obszarami społecznokulturowo-przyrodniczymi, pojawia się binarna opozycja człowiek-przyroda. Jej zastosowanie wprowadza inny rodzaj optyki: tutaj to pozbawiony konkretnej identyfikacji człowiek staje się sprawcą kolonizacji dokonywanej na przyrodzie. Daje to szeroką perspektywę, definiującą swoiście "genetyczne" cechy człowieka, 
warunkujące prowadzenie podbojów - czegoś lub kogoś. Warto w tym kontekście przywołać funkcjonujące w literaturze przedmiotu pojęcie "szowinizmu gatunkowego" (ang. Speciesism)11. Wprowadzone do obiegu przez Richarda Rydera, a rozpowszechnione przez Petera Singera ${ }^{12}$ oznaczać ma krytyczny stosunek do uzurpowanej przez człowieka dominacji nad innymi zwierzętami. Rozważania oparte na tym terminie zmierzają do podjęcia dyskusji, uświadomienia bezpodstawności tego, w ludzkim mniemaniu uzasadnionego, szowinizmu gatunkowego, a w końcu - do zmiany postaw ludzi i poprawy warunków bytowania zwierząt, współegzystujących z człowiekiem. Wprowadzenie pojęcia "szowinizmu gatunkowego" pozwoliło w sposób systematyczny podjąć rozważania nad moralnym prawem gatunku homo sapiens do wykorzystywania dla własnych celów innych gatunków. Traktowanie zwierzęcia jako podmiotu stanowi, jak wspomniałam, jeden z przejawów szerszego nurtu myślenia o otaczającej człowieka rzeczywistości, ze szczególnym naciskiem na dbałość o zrównoważony rozwój gatunku ludzkiego - czyli rozwój, który, wykorzystując obecnie dostępne zasoby, jednocześnie dba o ich zachowanie dla przyszłych pokoleń. Innymi słowy, chodzi o stan, kiedy zaspokajanie potrzeb obecnego pokolenia w żaden sposób nie umniejsza szans przyszłych pokoleń na zaspokojenie ich potrzeb.

Widzę tutaj następujące przejście. Pierwszym etapem zwrócenia uwagi na obecność praktyk kolonizacyjnych $\mathrm{w}$ odniesieniach przedstawicieli kultury europejskiej, do kultur pozaeuropejskich był krytyczny namysł nad tym, jak kultura zachodnia traktuje ludzi, którzy nie są jej przedstawicielami. Ten początkowy etap refleksji, rzeczywiście zapoczątkowany przez prace F. Fanona ${ }^{13}$, E. Saida ${ }^{14}$, kontynuowanej przez G. Ch. Spivak ${ }^{15}$, traktować należy jako pierwszy alarmujący sygnał, który na gruncie prowadzonych $\mathrm{w}$ ramach humanistyki rozważań racjonalno-naukowych podejmował zagadnienie kulturowej opresji. $Z$ pewnością korzeni tego nurtu można by dopatrywać się już w pracach przedstawicieli tzw. szkoły frankfurckiej (szczególnie Theodora Adorno16), traktujących o relacjach międzyetnicznych praktykowanych przez nazistów. Pierwsze impulsy do refleksji na temat opresyjnego kolonizowania były więc ukierunkowane na stosunek grup osób dominujących wobec grup osób zdominowanych.

Uświadomienie sobie istnienia nierówności społecznych w tym wymiarze traktowałabym jako czynnik spustowy, uruchamiający ewolucyjny w swym charakterze mechanizm pobudzania i wzmacniania przekładającej się na konkretne działa-

${ }^{11}$ R. Ryder, http://www.theguardian.com/uk/2005/aug/06/animalwelfare (data dostępu: 27.12.2014).

${ }^{12}$ Wobronie zwierząt, op. cit.

${ }^{13}$ F. Fanon, op. cit.

${ }^{14}$ E. Said, Orientalizm, op. cit.

${ }^{15}$ G. C. Spivak, The Post-Colonial Critic: Interviews, Strategies, Dialogues. London 1990.

16 T. Adorno, Der autoritäre Charakter. Amsterdam 1968. 
nia empatii, których realizacja miała prowadzić do zmiany negatywnie odczuwanej sytuacji. Tak więc refleksja krytyczna uświadamiała szerszemu odbiorcy fakt różnego traktowania ludzi oraz fakt wykorzystywania tych różnic do legitymizowania działań o charakterze moralnie nagannym lub przynajmniej dwuznacznym.

Drugim etapem walki z szeroko rozumianym kolonializmem można nazwać nurt dbałości o likwidację wszelkiego rodzaju dyskryminacji i wyrównywanie szans osób objętych dyskryminacją. W kontekście dyskursu postkolonialnego przywołuje się tutaj najczęściej opresyjnie traktowane w kulturze zachodniej kobiety oraz przedstawicieli i przedstawicielki nieheteroseksualnych orientacji płciowych.

Po tej drugiej fali krytycznego myślenia na temat kolonizowania $\mathrm{w}$ latach sześćdziesiątych w USA pojawia się nurt trzeci - refleksja, że człowiek kolonizuje nie tylko obszary zamieszkane przez ludzi oraz że kolonizację opisuje nie tylko wymiar kulturowo-społeczno-ekonomiczny. Ten zwrot przyjmuje postać gwałtownego uświadomienia opinii publicznej, że pierwotnym procesem kolonizacji było podbijanie przyrody, jej eksploatacja i zniszczenie. Zwraca na to uwagę Elżbieta Posłuszna w doskonałej publikacji na temat ekstremizmu ekologicznego:

Wtedy to po raz pierwszy zostało zakwestionowane przekonanie o korelacji między zwiększeniem eksploatacji przyrody a wzrostem dobrobytu. Jednocześnie do szerszych kręgów społecznych (głównie w USA) zaczęła przenikać świadomość możliwości wystąpienia ekologicznego kryzysu, który - jeśli do niego dojdzie - może zagrozić wszystkim żyjącym na ziemi gatunkom. [...]. Jak grzyby po deszczu zaczęły wyrastać organizacje, których celem było lobbowanie na rzecz środowiska naturalnego ${ }^{17}$.

Jest to, w mojej ocenie, trzecia, głębsza fala krytycznego myślenia na temat tego, jak człowiek zachowuje się wobec świata już nie tylko ludzkiego, ale wobec świata przyrody. Ten trzeci etap traktuję też jako wyraz osiągnięcia wyższego poziomu rozwoju moralnego i etycznego, dla którego świat otaczający człowieka pojmowanego jako gatunek zyskuje cechy podmiotowe, co więcej - podmiotowe w sensie szczególnym, bo uświadamiając sobie poczucie odpowiedzialności za to, co kolonizowane, szczególnie dlatego, że jest to niezdolne do aktywnego przeciwstawienia się kolonizacji. Pozwalam sobie na subiektywne przyznanie statusu wyższego poziomu moralnego tego rodzaju percepcji dlatego, że jest ona nierozerwalnie związana z zaspokojeniem podstawowych potrzeb tworzących bazę piramidy potrzeb zbudowanej przez Abrahama Maslowa ${ }^{18}$. Dopiero po zaspokojeniu wszelkich potrzeb fizjologicznych, bezpieczeństwa, afiliacji i samorealizacji, można w zasadzie myśleć o realizacji potrzeby sensu życia. Ta zaś wydaje się obejmować troskę nie tylko o siebie i własne potrzeby, ale rozszerzenie jej na inne

\footnotetext{
17 E. Posłuszna, Ekstremizm ekologiczny. Warszawa 2012, s. 9.

18 A. Maslow, Motywacja i osobowość. Przeł. P. Sawicka. Warszawa 1990.
} 
istoty ludzkie i pozaludzkie. Nie trudno się więc dziwić, że świadomość ekologiczna i prawa zwierząt są realizowane szczególnie intensywnie $w$ tych krajach, w których mierzony wartościami ekonomicznymi poziom życia jest wysoki i gdzie obywatele nie muszą martwić się o przetrwanie.

Wątpliwości może budzić stawianie człowieka w opozycji wobec przyrody. $\mathrm{W}$ mojej ocenie, człowiek jest nierozerwalnie związany z resztą świata przyrodniczego na tych samych prawach co inne zwierzęta. Traktuję homo sapiens jako gatunek tak samo uprawniony jak inne gatunki zwierząt (jest to zresztą podejście propagowane przez wielu badaczy zajmujących się etologią - Karola Darwina19, Frnasa de Waala ${ }^{20,21}$. Dlatego uważam, że klasyczny dylemat filozofów, koncentrujący się na pytaniu, gdzie przebiega granica pomiędzy naturą a kulturą, jest w swojej istocie bezzasadny, bowiem kulturę należy tutaj traktować jako specyficzny wytwór naturalnego zaplecza człowieka - rozwiniętego i zdolnego do abstrakcyjnego myślenia mózgu. Kultura jako wytwór niespotykanych zdolności ludzkiego intelektu stanowi o specyfice naszego gatunku, nie może jednak uprawniać do przyznawania mu praw bardziej rozległych, złożonych czy wyższych. Traktuję więc człowieka jako element współtworzący świat przyrodniczy. W tym sensie eksploatacja przyrody, będąca podstawową motywacją dla jej kolonizowania, jest dla mnie nieakceptowalna, a przynajmniej na tyle trudna do zaakceptowania, że prowokuje do konkretnych działań na poziomie empirycznym, zmierzających do ograniczania negatywnych skutków tejże eksploatacji22.

W tym miejscu warto też zwrócić uwagę na element niedostrzegany przez tych, którzy nadal należą do uzurpujących dla ludzi prawo do większych praw. Z faktu zdolności człowieka do abstrakcyjnego myślenia, zaawansowanego planowania, przewidywania i innych tym podobnych zdolności rozumowania wynika zobowiązanie: im bardziej rozwinięty sposób myślenia, tym wyższe oczekiwanie odpowiedzialności za własne czyny. Jeśli umieścić człowieka na piedestale pośród innych zwierząt, jeśli przyznać mu większe zdolności i możliwości, spo-

${ }^{19}$ K. Darwin, O wyrazie uczuć u człowieka i zwierząt. Przeł. Z. Majlert, K. Zaćwilichowska. Warszawa 1988.

${ }^{20}$ F. De Waal, Matpy i filozofowie. Skąd pochodzi moralność? Przeł. B. Brożek, M. Furman. Kraków 2013.

${ }^{21}$ F. De Waal, Bonobo i ateista. W poszukiwaniu humanizmu wśród naczelnych. Przeł. K. Kornas. Kraków 2014.

22 Ogromnie interesujące są w tym kontekście teksty popkultury. Doskonale obrazuje to reklama sprzętu do sprzątania: samotny, ocalony rozbitek, idąc brzegiem morza, natyka się na pudło z odkurzaczem. Włącza go, zaczyna "sprzątać” zielsko na wyspie i jego oczom stopniowo ukazują się: piękny betonowy pozbrukowy chodnik, śliczne nowe meble ogrodowe $\mathrm{z}$ techno rattanu, zewnętrzne schody obłożone ceramicznymi płytkami, wiodące do domu, w którym mieszka piękna młoda kobieta, kulturowa ikona atrakcyjności. Tak konstruowane przekazy wzmacniają binarną opozycję: człowiek-kolonizator wobec przyrody, świata kolonizowanego (por. https://www.youtube.com/watch? v=IH9 HpdOaTWE (data dostępu: 27.12.2014). 
cznie na nim automatycznie większa odpowiedzialność za jego czyny. Jeśli nawet uznać za prawomocne (moim zdaniem nieuprawnione) twierdzenie, że człowiek ma prawo do nieograniczonego korzystania z zasobów przyrody, jednocześnie należy na tegoż człowieka nałożyć moralny obowiązek dbania o to, z czego korzysta. Traktowanie człowieka jako gatunku w równym stopniu uprawnionego do korzystania ze świata naturalnego nie zwalnia go z odpowiedzialności za sposób korzystania z niego.

W kontekście powyższych rozważań związanych z kolonizowaniem przyrody, warto przywołać wydaną $\mathrm{w}$ języku polskim pracę Erica Barataya pod znamiennym tytułem Zwierzęcy punkt widzenia. Inna wersja historii ${ }^{23}$. Barataya uznać należy w zasadzie za pioniera nowej dziedziny badań humanistycznych - historii pisanej ze zwierzęcego punktu widzenia. W omawianej pracy autor stara się udowodnić, że dotąd historia była pisana zawsze z punktu widzenia człowieka. Nawet, jeśli wspominano o zwierzętach, to był to wątek niejako poboczny, pojawiający się $\mathrm{w}$ sąsiedztwie głównego nurtu rozważań - ludzkich losów. Takie patrzenie na świat jest wysoce antropocentryczne, argumentuje Baratay. Wskazuje następnie, jak zmiany ludzkiego świata i ludzkiego sposobu życia wpłynęły na historię zwierząt:

Inną konsekwencją postępującego od drugiej połowy XIX wieku bogacenia się Zachodu jest zwiększenie ilości wolnego czasu, co pozwoliło oddawać się rozrywkom, które stopniowo zyskują na znaczeniu, a wiek później są już istotną częścią codziennego życia. W niektórych $\mathrm{z}$ tych atrakcji wykorzystuje się zwierzęta, na przykład na polowaniu, jeździectwie i różnych „spektaklach": cyrku, zoo, walkach zwierząt i walkach z ludźmi. Jedna z nich, korrida, odniosła prawdziwy sukces i odbiła się szerokim echem intelektualnym, artystycznym i medialnym ${ }^{24}$.

Cytując afrykańskie przysłowie: „Dopóki lwy nie będą miały swego historyka, dopóty opowieści o łowach sławić będą myśliwego"25, Baratay dobitnie wskazuje, że każdy autor historii pokazuje ją z własnego punktu widzenia. Autorów może być więcej, więc punktów widzenia także. Zauważa przy tym:

Ciekawą rzeczą jest to, że dążenie do dokonania tego konceptualnego zwrotu, tego przesunięcia spojrzenia na zwierzę nabiera tempa. Kiedy podjąłem pracę nad tym tematem w 2007 roku, mogłem się tylko na nielicznych, dość świeżych głosach filozofów i antropologów [...] W 2011 roku, w chwili gdy poprawiam ten rozdział przed wydaniem, zwrot dokonuje się już $\mathrm{w}$ wielu dziedzinach: $\mathrm{w}$ zootechnice [...], w etnologii i socjologii, chcących ukazać status zwierząt, takich jak krowy mleczne albo psy do towarzystwa, jako zindywidualizowanych aktorów ${ }^{26}$.

\footnotetext{
${ }^{23}$ E. Baratay Zwierzęcy punkt widzenia. Inna wersja historii. Przeł. P. Tarasewicz. Gdańsk 2014.

${ }^{24}$ Ibidem, s. 31.

25 Ibidem s. 33.

${ }^{26}$ Ibidem, s. 3.
} 
Dla porządku należy jednak dodać, że na gruncie archeologii, historiografii i metodologii historii są już prowadzone prace, mające na celu wskazanie, że historia nigdy nie jest odtwarzana, ale zawsze tworzona przez jej odkrywcę, który poprzez swoje kulturowe okulary interpretuje odkryte artefakty, nakładając na nie znaczenia zakorzenione w macierzystej (lub, po prostu, tej znanej) kulturze. Już w latach osiemdziesiątych pisał na ten temat szeroko Ian Hodder - jego opublikowana wspólnie z Scottem Hutsonem praca zatytułowana Reading the Past. Current approaches to interpretation in archaeology ${ }^{27}$ po raz pierwszy wydana została $\mathrm{w} 1986$ roku. Autorzy zwracali w niej uwagę właśnie na "czytanie" a nie "odkrywanie" historii, wskazując tym samym na niezbywalną rolę procesów interpretacyjnych wynikających z obecnej własnej, indywidualnej sytuacji historyka i rzutującej na to, jak "odczytuje" on historyczne czy archeologiczne artefakty. Ten nurt myślenia był w Polsce rozwijany przez metodologiczną szkołę historiografii i metodologii historii Jerzego Topolskiego.

Przytaczając wiele danych statystycznych, E. Baratay próbuje pisać historię widzianą okiem zwierząt. Autor podkreśla jednak, jak trudne jest przyjęcie optyki, w myśl której ludzie musieliby przynajmniej uznać, że zwierzęcy punkt widzenia istnieje, że zwierzęta się komunikują i że czynią to inaczej niż człowiek. "Inaczej” nie znaczy "gorzej”, co więcej - w wielu sytuacjach znaczy „lepiej”. Tak jak w przypadku historii tworzonych przez historyków, tak i tutaj mamy do czynienia z procesem (najczęściej nieuświadamianej) projekcji:

Ludzie dostrzegają, rzecz jasna, jedynie część tych przeżyć i znaków, interpretując je $\mathrm{z}$ łatwością wedle własnych kodów, ale jest to problem, który pojawia się w przypadku wszystkich Innych. Co rozumie europejski etnolog zajmujący się innymi populacjami? Wiemy, że balansuje pomiędzy aplikowaniem własnych interpretacji, $\mathrm{w}$ tym tych najbardziej uczonych, jak na przykład strukturalistyczna, oraz pragnieniem uchwycenia danej rzeczywistości; cała historia etologii jak i etnologii naznaczona jest tym dylematem ${ }^{28}$.

Praca Barataya zmierza ku wskazaniu, jak dążenie człowieka do utrzymania supremacji nad światem ożywionym znajduje swój wyraz w stosowaniu strategii deprecjonowania tego świata. Zawiera się to w cytowanej przez Barataya wypowiedzi Claude'a Lévi-Straussa: „Każdy człowiek był, jest i będzie zawsze jedyny. Ale człowiek nie różni się pod tym względem od innych istot żyjących, nawet najmniejszych, których unikatowego statusu nie myśli wcale respektować" 29 .

Bataray zwraca uwagę na to, że zwolenników podmiotowego myślenia o zwierzętach inspirują i inspirowały prace Bruno Latoura ${ }^{30}$ o czynnej roli otaczających

${ }^{27}$ I. Hodder, S. Hutson Reading the Past. Current approaches to interpretation in archaeology. Cambridge 2003.

${ }^{28}$ E. Baratay, op. cit., s. 273.

${ }^{29}$ Ibidem, s. 327.

${ }^{30}$ B. Latour, Polityka natury. Przeł. A. Czarnacka. Warszawa 2009. 
nas obiektów. Traktowane jako aktorzy przedmioty zmieniają relacje i interakcje społeczne. Zaklasyfikowanie zwierząt w pierwszej kolejności jako „przedmiotów” otaczających człowieka pozwala Latourowi nadać im status aktywnie oddziałujących na niego aktorów. Aktor zaś jest nie tylko upodmiotowiony, ale ma moc oddziaływania, która porusza widza. Takie rozumowanie, choć z początku budzące opór, w końcu pozwala przyznać zwierzęciu status aktywnego i świadomego aktora.

Baratay proponuje poszerzoną definicję Lévinasowskiego „Innego":

Aż do dziś, pośród Innych badacze sytuowali jedynie części ludzkiej populacji: kobiety, niewolników, społeczności żyjące poza danymi granicami, pod wpływem etnocentryzmu często zwane barbarzyńskimi albo prymitywnymi, i to nie tylko w Europie, ale wszędzie indziej ${ }^{31}$.

Potraktowanie zwierząt jako Innych podkreśla ich dotąd negowaną podmiotowość. Oznacza to taką samą przemianę, jaka zdarzyła się w przypadku myślenia o ludziach nie-z-Europy: „Portret zwierzęcia podlega zatem wariacjom: organizm wytresowany, by reagować, uwarunkowana genetycznie żywa istota, maszyna przetwarzająca różne problemy, świadomy byt obdarzony podmiotowością..."32. Idzie więc o to, by do bycia wobec zwierząt, zaimplementować osiągnięcia relatywizmu kulturowego, wypracowane na gruncie antropologii, etnologii i filozofii. Posługiwanie się kategorią Innego w stosunku do zwierząt pozwala na inne na nie spojrzenie: empatyczne, humanitarne i podmiotowe.

W tym miejscu dochodzimy do punktu, w którym warto spojrzeć na problem, z poziomu "meta": zbliżam się więc do podjęcia zagadnienia tytułowych metastrategii kolonizowania świata przyrody. Postrzegam je jako spójny, powiązany ze sobą system trzech metastrategii - szczególnie jeśli realizowanych konsekwentnie - pozwalających na wytworzenie konstruktu, który określiłabym mianem „postawy kolonizatora". Otóż doskonale funkcjonująca na gruncie socjologii i psychologii społecznej, powszechnie przyjmowana definicja "postawy” określa ją jako trwały konstrukt złożonych z trzech komponentów: emocjonalnego, behawioralnego i poznawczego (co zgrabnie w literaturze anglosaskiej określa się mianem modelu $\mathrm{ABC}$ - affection, behavior, cognition). W tym sensie proponowałabym przyjęcie istnienia trzech metastrategii, pozwalających na wykreowanie, utrzymanie i realizowanie postawy kolonizującej. Model ten ma charakter na tyle ogólny, że może być stosowany nie tylko $\mathrm{w}$ analizach procesu kolonizowania przyrody, ale także w każdym innym, możliwym do pomyślenia przypadku kolonizacji. Nazywam więc wymienione strategie, strategiami typu „meta”. Trudność, jaka tutaj się

\footnotetext{
${ }^{31}$ E. Baratay, op. cit., s. 39.

32 Ibidem, s. 46.
} 
pojawia, polega na jednoznacznym określeniu, która z omawianych trzech metastrategii jest tą pierwotną, a które - pochodnymi. Niezaprzeczalnie wszystkie trzy pozostają $\mathrm{w}$ interaktywnym, dynamicznym związku. Im bardziej są zgodne $\mathrm{w}$ swoim znaku, tym końcowy konstrukt $\mathrm{w}$ postaci postawy, będzie trwalszy i trudniejszy do modyfikowania.

Metastrategia językowa pozwala na opis świata. Ma wymiar kognitywny, poznawczy, pozwala formułować sądy i opinie, nie zawiera elementu emocjonalnego, ale może oczywiście być wykorzystywana do nazywania uczuć i emocji. Ludwig Wittgenstein doskonale określił, że granice języka są jednocześnie granicami poznawczo dostępnego świata ${ }^{33}$. Chociaż lingwiści, tłumacze i filozofowie spierają się jak ostatecznie opinia ta powinna być dokładnie interpretowana, to jej sens jest czytelny: język wytycza ramę percepcji świata. Im bogatszy, bardziej zróżnicowany, tym bardziej zróżnicowany jest widziany świat. Im język prostszy, tym prostsze widzenie (czyli - rozumienie) otoczenia. Druga koncepcja, którą tu warto przywołać jako wsparcie dla tezy, że językowe ramy nazywania świata, wpływają na pozostałe metastrategie wchodzące w skład postawy kolonizującej, to koncepcja wypowiedzi performatywnych Johna Austina ${ }^{34}$. Tym mianem określa się szczególny rodzaj mowy, który jest zarazem działaniem. Mamy tu do czynienia nie tylko $\mathrm{z}$ nazywaniem świata i nadawaniem mu znaczeń, ale $\mathrm{z}$ uruchamianiem konkretnych zachowań, skutkujących realnie odczuwalnymi zmianami. Prócz aspektu logicznego, pojawia się tutaj aspekt bezpośredniego oddziaływania języka na rzeczywistość otaczającą podmiot poznający. Jest to szczególnie istotne w kontekście prowadzonego wywodu, bowiem zarysowuje związek pomiędzy kolonizacyjną metastrategią językową, a metastrategią behawioralną, o której poniżej.

Doskonałą egzemplifikacją stosowania języka w taki sposób, który podlega ujęciu Wittgensteinowskiemu i Austinowskiemu, jest przykład języka stosowanego przez myśliwych. Ilustracja funkcjonowania wspólnoty myśliwych zostanie także wykorzystana poniżej dla zobrazowania kolejnych dwóch metastrategii: zachowaniowej i emocjonalnej.

Dystansowanie się wobec ofiary ma tutaj ekstremalny wymiar. Zwierzę traktowane jest jako przedmiot, element, który ma służyć ludzkiej rozrywce. To odbierające godność i podmiotowość, odmawiające uznania zwierzęcia za aktora podejście znajduje odzwierciedlenie w języku. Krew to "farba”. Serce to „komora”. Postrzelone zwierzę - "postrzałek” i tak dalej. Zbudowanie bariery werbalnej pozwala na separowanie się myśliwego wobec uczuć zwierzęcia. Pozwala zabijać bez wyrzutów sumienia. Tego rodzaju praktyki stosujemy w codziennym życiu, na przykład nazywając wnętrzności zwierząt „podrobami” czy mówiąc, że zwierzę

\footnotetext{
${ }^{33}$ B. Wolniewicz, Wstęp do Tractatus Logico-Philosophicus. W: L. Wittgenstein, Tractatus LogicoPhilosophicus. Przeł. B. Wolniewicz. Warszawa 1970.

34 J. L. Austin, Mówienie i poznawanie. Przeł. B. Chwedeńczuk. Warszawa 1993.
} 
„zdycha”, podczas kiedy człowiek - „umiera”. Martwe zwierzę to „padlina”, martwy człowiek - "trup". To ta sama konwencja dystansowania się za pomocą specyficznego języka. Stosowanie go jest jednak wyrazem pewnej strategii kognitywnej, patrzenia na świat ożywiony w sposób hierarchiczny. Pierwotna jest więc percepcja świata, wtórne - stosowanie określonego języka a następnie uruchamianie konkretnych zachowań.

Metastrategia behawioralna wynika więc poniekąd z metastrategii językowej, wzmacnia ją i legitymizuje. Przyjęcie jako słusznej choćby koncepcji performatywnych aktów mowy Austina tłumaczy akty behawioralne. Skoro zwierzę zostaje nazwane "przedmiotem”, automatycznie uruchamia działania ukierunkowane przedmiotowo. Pozwala wykorzystywać i instrumentalizować, bo przecież temu służą przedmioty. Wspomniany już przykład języka myśliwych, prócz dzielenia elementów świata na podmioty i przedmioty, wspiera ich zachowania poprzez inny jeszcze mechanizm - wskazanie istnienia grupy. Znajomość specyficznego języka, jakim posługuje się wspólnota (im bardziej zamknięta, tym bardziej jej język jest hermetyczny i niezrozumiały dla osób spoza niej), pozostaje jednoznacznym dowodem na przynależność do tejże właśnie grupy. Poczucie przynależności do społeczności, uruchamia zaś psychospołeczne procesy grupowe, w szczególności konformizm i dyfuzję odpowiedzialności. Pierwszy powoduje, że członkowie grupy żyją w subiektywnie wytwarzanym, a społecznie utrwalanym przekonaniu, że pewne zachowania są właściwe, a inne - nie. Pomimo tego, że jednostka mogłaby się wewnętrznie nie zgadzać ze słusznością zachowań czy sądów, obecność grupy uruchamia presję upodobnienia się do większości. Drugi mechanizm powoduje odrzucanie odpowiedzialności za swoje zachowanie („robię tak jak inni” lub „niech zareaguje ktoś inny, jest tu tyle osób”). Dostrzegam tutaj następujący mechanizm: przyjęcie języka grupy pozwala nazwać świat i poczuć przynależność do społeczności. To zaś uruchamia mechanizm samoutwierdzania się w słuszności własnych zachowań (psychologicznie: racjonalizuje). Zachowania uznawane są za słuszne, bowiem wytłumaczone zostają tradycją, etosem, społecznym dowodem słuszności (opartym na fakcie, że inni zachowują się w taki sam sposób). Nie tylko więc język uruchamia przedmiotowe traktowanie świata ożywionego, ale funkcjonowanie w grupie społecznej, która cała postrzega świat identycznie (bardzo podobnie) legitymizuje jako słuszne własne podejście do stanu rzeczy. Przywołana wcześniej egzemplifikacja społeczności myśliwych jest trafna także $\mathrm{w}$ tym przypadku. Dla przykładu, wielu myśliwych uznaje za uprawniony rytuał picia alkoholu w trakcie polowania. Przywołany cytat wskazuje dobitnie na obecność omówionych przez mnie wcześniej elementów:

Dla mnie polowanie bez "oblewin”, to jak wesele bez muzykantów. Oblewam mniej więcej każdą strzeloną sztukę zwierza. Gdy strzelę byka, to jest wesele. Nie wstydzę się o tym pisać, ponieważ nie uważam tego za nic zdrożnego. Nie znam w okolicy koła, 
w którym myśliwi piją po polowaniu oranżadę. Biesiady zakrapiane alkoholem integrują myśliwych i nie widzę powodów, aby to potępiano. Z praktyki wiem, że każda jakakolwiek impreza bez gorzałki, kończy się po godzinie. Gdy jest na niej gorzałka, balety trwają do rana i o to chodzi, a jak są jeszcze kobitki, to już więcej do szczęścia nic nie potrzeba. Nadmieniam, że nie jestem uzależniony. Pozdrawiam wszystkich nie mogących spożywać. Nie wstydźmy się tego. DB5.

W cytacie uwidacznia się zarówno stosowanie języka uruchamiające dystansowanie się emocjonalne (np. „strzelę byka”, a nie „zabiję byka”); elementy racjonalizujące zachowania (,polowanie bez »oblewin« to jak wesele bez muzykantów") oraz uprzedmiotawiające (gorzałka i kobitki: stawiane na tym samym poziomie „przedmioty” niezbędne dla dobrej zabawy) ${ }^{36}$.

Wreszcie trzecia wspomniana metastrategia: emocjonalna. Oczywistym jest, że za pomocą językowego kategoryzowania obiektu i klasyfikowania go uruchamia się proces racjonalizowania (myślenia o tym obiekcie $\mathrm{w}$ nadanych mu kategoriach), a co za tym idzie - konkretne zachowania oraz emocje. Stosowanie języka dystansującego się i klasyfikującego obiekt (zwierzę) jako przedmiot, a nie podmiot, pozwala go "strzelać”, a nie "zabijać”; pozwala też świętować zdobycie trofeum (przedmiot), a nie płakać nad straconym życiem (podmiot). Proponuję przyjąć, że nie można jednoznacznie wskazać, jaki jest porządek pojawiania się i uruchamiania tych metastrategii i że może on być zmienny. Sugeruję także, by uznać ich interaktywny charakter w tworzeniu postawy, którą ostatecznie nazywam „postawą kolonizującą”. Zakładam, że wyróżnione trzy metastrategie mogą być uruchamiane w różnej kolejności, a kolejność tę definiowałabym jako wynik sytuacji (np. rozdeptałem owada. „To tylko robak”. Pierwsza pojawia się strategia emocjonalna, która służy uzyskaniu dystansu wobec zabicia owada, ale pojawia się na skutek zajścia zdarzenia. "To robak”, więc mogę go zabić, bo mnie ugryzie kategoryzowanie owada jako przedmiot, na dodatek groźny, co uprawnia do zabicia). Drugi czynnik wpływający na uruchamianie wyróżnionych metastrategii to proces socjalizacji oraz wynikający z niego i z własnej aktywności podmiotu działającego system zinternalizowanych wartości.

Dla egzemplifikacji wyróżnionych trzech metastrategii posłużył mi przykład społeczności myśliwych, jednak identyczne procesy można zaobserwować w przypadku takich grup zawodowych, jak lekarze czy weterynarze, pracownicy socjalni, terapeuci, eksperymentatorzy prowadzący doświadczenia na zwierzętach. Te grupy zawodowe szczególnie narażone są na negatywne zjawisko przej-

35 http:/ / dziennik.lowiecki.pl/ forum.php?f=11\&t=323803\&numer=1634_data dostępu: 17.02.2015).

36 Wyraźnych dowodów na to jak język uruchamia konkretne zachowania jest wszak proponowana przez Basila Bernsteina koncepcja socjolingwistycznych kodów, które poprzez język definiują sytuacje społeczne a w konsekwencji uruchamiają konkretne zachowania ludzi: B. Bernstein, Class, Codes and Control v.1: Theoretical Studies Towards Sociology of Language, London 1971. 
mowania emocji pojawiających się $\mathrm{w}$ ich pracy $\mathrm{w}$ stosunku do ludzi i zwierząt nieludzkich, którzy (które) są odbiorcami ich świadczeń lub są bezpośrednio narażone na ich działania (eksperymenty). Dystansowanie się w stosunku do nich, jak i ich problemów stanowi technikę budowania emocjonalnych barier, co ma skutkować lepszymi efektami w pracy i możliwością - na przykład - wykonywania bolesnych zabiegów. W tych przypadkach mamy jednak również do czynienia z postawą, którą określam właśnie mianem kolonizującej, a która hierarchizuje świat, przyznając jego elementom określone miejsce $w$ subiektywnie wyznaczonym porządku, sankcjonowanym przez subiektywnie dobierane racjonalizacje.

\section{KONKLUZJA}

W połowie lat sześćdziesiątych i na początku siedemdziesiątych zaczęły aktywizować się ugrupowania, których celem było dokonanie inwersji w postrzeganiu relacji człowiek - reszta świata. W zasadzie zmierzały one do podkreślenia, że dalsze nieokiełznane kolonizowanie przyrody spowoduje nieodwracalne skutki ekologiczne, a dalej - społeczne i dlatego niezbędne jest aktywizowanie społeczeństwa w kierunku świadomie realizowanej konsumpcji, jej ograniczania i racjonalizowania: „Momentem zwrotnym w kształtowaniu się zielonego ekstremizmu była decyzja amerykańskiej rządowej agencji lasów państwowych [...], o przeznaczeniu 36 milionów akrów obszarów leśnych do komercyjnej eksploatacji"37. Decyzja ta wykazała brak proekologicznego myślenia agend rządowych w USA a ponadto stała się czynnikiem katalizującym radykalizację ruchów społecznych walczących o poszanowanie przyrody i ograniczanie jej eksploatacji. Od tego czasu obserwować możemy coraz dynamiczniejszy rozwój organizacji prośrodowiskowych, animalistycznych, także ich radykalizowanie się, a z drugiej strony - upowszechnianie wyrażanych $\mathrm{w}$ łagodniejszej formie strategii oporu wobec kolonizowania przyrody.

W kontekście debaty nad postkolonializmem rysuje się jeszcze jedno interesujące zagadnienie związane z dyskryminacją, którego istnienie tutaj tylko zasygnalizuję - jest to "niesprawiedliwość środowiskowa” (environmental injustice) albo "dyskryminacja środowiskowa". Ten niedawno zauważony aspekt kolonizowania i konsekwencji z nim związanych wyraża się w dyskryminacji. Okazuje się bowiem, że kolonizowanie przyrody skutkuje także negatywnymi reperkusjami dla ludzi, a w szczególności tych grup, które są nisko uposażone ekonomicznie. Przedstawiciele tych i dyskryminowanych $\mathrm{z}$ innych względów grup społecznych są narażeni na mieszkanie $\mathrm{w}$ obszarach zdegradowanych środowiskowo. Poza

${ }^{37}$ E. Posłuszna, op. cit., s. 9. 
innymi negatywnymi konsekwencjami kolonizowania przyrody istnieje tu również problem, na który dotąd niemal nie zwracano uwagi. Dodać należy, że dyskryminowane z różnych względów grupy społeczne zazwyczaj mają utrudniony dostęp do zasobów finansowych i ich możliwości ekonomiczne są mniejsze niż grup uprzywilejowanych. Na dyskryminację rasową, etniczną, płciową, ze względu na wiek i inne nakłada się kategoria dyskryminacji poprzez niepełnowartościowe środowisko życia.

Nietrudno zauważyć, że metastrategie kolonizowania przyrody pokrywają się ze strategiami, które stosowano w celu kolonizowania obszarów definiowanych kulturowo i że w zasadzie, jak wspomniałam powyżej - mogą być stosowane do każdego pomyślanego procesu kolonizacji. Wyróżnione trzy metastrategie to: strategia językowa/kognitywna, strategia behawioralna i strategia emocjonalna. Wymiar kognitywny sprowadza się do produkcji dyskursów deprecjonujących świat zwierząt, konstruowania nauk uprawomocniających takie postępowanie (przykładem może być przywoływana wyżej historia), legitymizowania działań o charakterze instrumentalnym, służącym eksploatacji. Ponadto depersonalizacja i deprecjacja pojedynczych zwierząt, odbierająca im status aktorów oraz uprzedmiotowienie, sprowadzające je do poziomu biernych przedmiotów, pomagają konstruować poznawcze bariery pomiędzy tym, co ludzkie, a tym, co pozaludzkie. $\mathrm{W}$ mojej, i nie tylko mojej, ocenie, jest to podział sztuczny a nawet fałszywy, ale pozwalający ludziom utrzymywać $\mathrm{w}$ mocy ich sądy, usprawiedliwiać działanie i kolonizować. Tworzenie osobnych języków do opisywania świata zwierząt, czy szerzej do opisywania świata przyrody i do mówienia o świecie ludzi, w doskonały sposób pozwala wzmacniać te kognitywną barierę ${ }^{38}$. Stosowany jest tu język uprzedmiotawiający, a więc taki, który używa słów deprecjonujących kulturowo („zdychać" zamiast „umierać"; "padlina” zamiast "martwe ciało”; "mięso” zamiast "trup") oraz taki, który dokonuje metamorfozy podmiotu w przedmiot: („drzewo" - „drewno”, „świnia” - „żywiec”, itd.). Spojrzenie na pole antropologiczno-etnologiczne pozwala dostrzec wyraźne analogie (człowiek cywilizowanybarbarzyńca, ludy prymitywne-ludy rozwinięte). Warto przypomnieć, co Ludwig Wittgenstein twierdził o wzajemnej interakcji zachodzącej między językiem a światem poznawanym: że granice języka są granicami poznania. Etykietowanie za pomocą kategorii językowych jest tutaj także istotną egzemplifikacją tego, jak stosowanie języka organizuje percepcję świata. Druga metastrategia behawioralna, jest realizowana dzięki istnieniu poprzedniej, za sprawą podziału świata na godny i niegodny uwagi i troski; dzięki stosowaniu odrębnego nazewnictwa $\mathrm{w}$ jednym przypadku mamy do czynienia ze światem traktowanym podmiotowo, $\mathrm{w}$ drugim - ze światem traktowanym przedmiotowo. Wreszcie metastrategia trzecia - emo-

38 Z. Kruczyński, Piękne, wolne, ginace. W: Śmierć zwierzęcia. Red. M. Kotyczka. Katowice 2014, s. 21-29. 
cjonalna pozwala na budowanie barier emocjonalnych, odcięcie się od „przedmiotu", na którym dokonuje się operacji.

Opisane trzy strategie mają bez wątpienia status metastrategii. Tak samo jak były aplikowane $\mathrm{w}$ stosunku do Innych kulturowo, tak są stosowane wobec Innych przyrodniczo. Ich odtwarzanie i utrzymywanie pozwala na budowanie postawy kolonizującej. Ta zaś, poprzez wzajemne wspieranie się składowych metastrategii, zyskuje na sile i trwałości. 